\title{
Participants' Perceptions on English Teacher Professional Program In Developing Teachers' Competence towards National Education Standards of Indonesia and ASEAN Economic Community
}

\author{
Ade Windiana Argina \\ LPDP (Indonesia Endowment Fund for Education) Awardee \\ Master in English Education, Universitas Pendidikan Indonesia \\ adewindianaa@student.upi.edu
}

\begin{abstract}
Considering the alarming phenomena in South East Asia, $21^{\text {st }}$ century demands and ASEAN Economic Community (AEC) programmes, the ASEAN Socio-Cultural Community (ASCC) and the ASEAN 5-year Work Plan on Education stress their focus on the quality improvement of education, teachers qualification and teacher education in purposing to reach the Education for All (EFA) goals, Millennium Development Goals (MDGs') and Sustainable Development Goals (SDGs). Indonesia, being one of ASEAN countries, which stands on a quality-oriented paradigm in teachers' professionalism requires qualified professional teachers with undergraduate degree and training in developing teachers' competences. It is reflected from several programmes launched. A one-year pre-service post-graduate program, namely Program Profesi Guru (PPG) or Teacher Professional Program, is one of several programmes instituted by government. This study firstly describes how this program is run including program management, curriculum implemented and program implementation. Through close-ended questionnaires given to whole 16 participants of PPG for pre-service teachers of English in Indonesia University of Education, in academic year 2016 to 2017, researcher tried to discover participants' perceptions towards the effectiveness of PPG implementation in developing their competence (based on National Education Standards of Indonesia) and the PPG implementation in meeting the ASEAN Economic Community Programmes demands (based on ASEAN sourcebook). The data were analysed by employing descriptive statistic to compare how significant the difference of those two different perception groups in terms of positive acceptance. This study found the difference between those two groups of perception towards the effectiveness of PPG implementation. The participants showed their positive response more significantly toward the PPG implementation in developing their competence than toward the PPG implementation in developing their competence to support them on meeting the ASEAN demands. This result reflected that the participants considered the PPG implementation was lack of effectiveness in preparing teachers to meet ASEAN Economic Community demands.
\end{abstract}

Keywords: Teachers' perception, Indonesian Teacher Professional Education, Indonesian English Teacher Training, National Education Standards of Indonesia, ASEAN Economic Community.

\section{Introduction}

The era between 20th and 21st century is notable with the progressive era in which many aspects have dynamically and rapidly grown and developed in the global world including political changes, economic growth and educational challenges. The countries in Southeast Asia emerging under the Association of Southeast Asian Nation (ASEAN) by 2015 have approvingly made commitment to set and achieve the goals under the major pillars: ASEAN Political -Security Community (APSC), ASEAN Economic Community (AEC) and ASEAN Socio-Cultural Community (ASCC). More specific, the most conspicuous pillar is ASEAN Economic Community (AEC) in which specific goal of ASEAN has been set focusing on the economic integration, growth and development in the circle of ASEAN countries, particularly the innovation in trading and servicing and the facilitation of investment. This issue has led ASEAN Member States to prepare to meet this challenges, growth and development. Dealing with it, several variables significantly working should be integrated each other involving human resources, natural resources, political aspect, economic aspect and more specifically, educational aspect. The essence of education has been stated in [1] which emphasizes that "the education sector is expected to contribute to the establishment of a socially responsible ASEAN. In line with Richard, he explored one of beliefs as foundation of education stating that the role of educational program is to produce learners who are economically productive to meet the society needs [2]. 
As 21 st century brings us to the much more complex changes and challenges that are extremely different from other centuries have, which is characterized by the emergence of widely-use and widely-involvement of technology and broadly demanding of many skills related to high standard uses of language, ASEAN Economic Community provides crucial potential and great challenges for All ASEAN members with several implemented principles such as: allowing free movement of labourers, goods and capital; creating creative regional market that is economically competitive, integrated into the global economy and characterized by more equitable developments [3]. The ASEAN Socio-Cultural Community, explicitly explores English language capacitybuilding in its blueprint, along with educational investment, life-long learning, human resource training and capacity-building, and applying technology [4]. To be strengthened, based on Permendiknas (Regulation of the Indonesian Ministry of Education No.22 Year 2007 cited in Suherdi, Multilingualism is increasingly needed as it is required to get wider access to global learning resources as well as to develop international interaction and relations for both social and business process [5]. Hence, although language capacity is often specifically unmentioned in ASEAN documents, it is undeniable that language is one of fundamental factors in the achievement of those demands and integrations.

Considering the alarming educational phenomena faced by ASEAN states, 21st century demands and ASEAN Economic Community (AEC) program, The ASCC and The ASEAN 5-year Work Plan on Education stress their focus on: the quality improvement of education; teachers; and teachers education in purposing to reach the Education for All (EFA) goals, Millennium Development Goals (MDGs) and Sustainable Development Goals (SDGs). As consequences, teachers in all ASEAN states need to concern more on the quality of education teachers and education teachers. Brown escalated broad area of teacher education concept in which teachers never stop learning to deal with many number of questions to answer, problems to overcome and issues to ponder [6]. Educational system for English education is expected to develop and improve excellent language competence, effective teaching ability, and empowering educating ability [7].As also underlined by Shaeffer, there seems to be the need for developing much more comprehensive and systematic approaches to educating (and re-educating) teachers [8] .However, as stated by Freeman observed, language teacher education has become increasingly fragmented and unfocused in which based on kaleidoscope of elements from many different disciplines, efforts to educate individuals as language teachers often lack a coherent, commonly accepted foundation [9]. Hence, specifically in Indonesia, our depth attention that should be put on the forefront is professional teacher. Indonesia requires qualified professional teachers with undergraduate degree and training in developing teachers' competences reflected by several programs launched. Teachers in many countries are currently trained at multipurpose universities; many teacher-training institutes have been transformed into comprehensive universities to improve quality oriented education [10]. Four main competences based on National Standards of Education in Indonesia, are Pedagogical Competence, Personality Competence, Social Competence and Professional Competence [11].

- Pedagogical competence is claimed as the core of teacher profession that must be developed perfectly by all teachers. Pedagogical competence is a comprehensive concept covering all abilities to construct learning successfully in various context of classroom. The concept includes the ability in planning, implementing, assessing and developing reflection activity and doing effective follow-up. Having this competence helps teachers plan learning activities and recognize students' various characteristics, so that teachers can adjust the learning activities with students' characteristics. This competence also guides the teachers to develop learning experience that challenges and motivates students to achieve their purposes. Several ways are proposed to help teachers develop their pedagogical competence such as being care and productive; learning from others, being a role model by showing competence, and taking upon to try.

- Personality competence is identical to the moral value such as right or wrong and good or bad. Teaching is not only about transferring knowledge and developing skills. Fundamentally, it covers two dimensions: dimension of performance related to intellectual capacity and dimension of morality related to moral education. In line with Aristotle stating that "education is the creation of sound mind and sound body. It develops man's faculty specially his mind so that he may be able to enjoy the contemplation of supreme truth, goodness and beauty." Thus, it can be concluded that personality competence is the ability to choose the best moral choice done by teachers in doing their rights and obligations as a teacher. This competence can be developed through making ourselves to be accustomed to select and to be committed toward the best moral choices; trying to keep consistent and keep sharing good deeds. 
- Professional competence is said as the competence of study field since it relates to the competence of subject taught by teachers. For English teacher, the professional competence includes real communication ability in English and English language systems such as grammar, vocabulary, pronunciation, and so on. It is analogized by "ingredients" of foods. No matter how superior a cook in cooking is, without ingredients he or she cannot do anything. Comprehensive mastery of this competence will lead teachers to acquire, choose and select, and present it in good quality and good performance to gain good result and satisfaction. This competence can be developed through analysing and beating the standard content, testing standard content acquisition, watching relevant video, doing peer exercising, and being accustomed with real communication.

- Social competence engages the ability of understanding, appreciating, and constructing harmonious relationship with students, students' parents, other teachers, colleagues, all school elements and society. It can be constructed by developing self-awareness toward the importance of building interaction, being forgivable, being humble and friendly with others.

One of several programmes instituted is a one-year pre-service post-graduate program, namely Program Profesi Guru (PPG) or Teacher Professional Development. Mrowcki proposed that one of the processes of developing a competency based curriculum is by reviewing existing curricula for example by gathering the information about the participants' perception toward the curriculum [12]. Therefore, this study was conducted focusing on the PPG for English Teachers in Indonesia, how it is implemented in general and participants' perception toward the PPG implementation in developing their competences, and participants' perception toward the PPG implementation in meeting the ASEAN demands, specifically ASEAN Economic Community based on ASEAN sourcebook. The ASEAN sourcebook covers 5 themes: valuing identity and diversity, connecting local and global [13] : (1)Knowing ASEAN deals with Learning about ASEAN (its structure, membership, purpose, and approach) and exploring ASEAN' significance, accomplishments and future challenges. (2) Valuing Identity and Diversity bounding up with Exploring the complex connection and influences shaping culture and beliefs, and recognizing and appreciating the strength embodied in the commonalities of people as well as their distinctive characteristics. (3) Connecting Global and Local engages with investigating how local issues are shaped by global developments and trends, and how local events in ASEAN influence global realities. (4) Promoting Equity and Justice strongly bounds up with fostering principles of fairness and equality and providing learners with tools and references for analysing complex situation and responding appropriately. And (5) Working Together for Sustainable Future relates to recognizing the pressures brought on by limited resources and growing populations and the implications for sustainability, while inspiring learners to work together within their communities and beyond so they might build a prosperous, peaceful and sustainable future for ASEAN.

This study employed mixed method approach in which the data were collected and analysed quantitatively and qualitatively. Qualitative approach was conducted to gather the information about the program of PPG through analytical literature from provided documents, literatures and other resources. Meanwhile, quantitative approach was employed to gather the data regarding to participants' perceptions towards the implementation of the Teachers' professional Development Program in Indonesia through questionnaire. The questionnaire consists of 72 closed-ended questions divided into two major groups. First, 51 questions related to their perceptions towards PPG in developing their four basic competences based on National Education Standards of Indonesia which were adopted from Martya [14] (pedagogical competence 11 questions, professional competence 10 questions, social competences 14 questions and personality ccompetence 13 questions). Second, 21 questions formulated based on ASEAN sourcebook related to their perceptions toward PPG implementation to support their competence to meet ASEAN Economic Society needs. The questionnaires were given to all of 16 participants of PPG Batch Four in Academic Year 2016 to 2017. Then, the data gathered were analysed through descriptive statistics to describe and draw the conclusion. The data were categorized by using 5 categories or scales based on Saifuddin Azwar [15]: extremely positive, positive, intermediately positive, negative and extremely negative as follows. 
Table.1 Category of Participants' Perception

\begin{tabular}{lc}
\hline \multicolumn{1}{c}{ Category } & Frequency \\
\hline Extremely Positive & $\mathrm{X}>(\mathrm{Mi}+1,5 \mathrm{SDi})$ \\
\hline \hline Positive & $(\mathrm{Mi}+0,5 \mathrm{SDi})<\mathrm{X} \leq(\mathrm{Mi}+1,5 \mathrm{SDi})$ \\
\hline \hline Intermediately Positive & $(\mathrm{Mi}-0,5 \mathrm{SDi})<\mathrm{X} \leq(\mathrm{Mi}+0,5 \mathrm{SDi})$ \\
\hline \hline Negative & $(\mathrm{Mi}-1,5 \mathrm{SDi})<\mathrm{X} \leq(\mathrm{Mi}-0,5 \mathrm{SDi})$ \\
\hline \hline Extremely Negative & $\mathrm{X} \leq(\mathrm{Mi}-1,5 \mathrm{SDi})$ \\
\hline \hline
\end{tabular}

Symbols' Explanation:

Mi $($ Mean Ideal $)=1 / 2($ Highest Score+ Lowest Score $)$

SDi (Ideal Standard Deviation Ideal) = 1/6 (Highest Score - Lowest Score)

$\mathrm{X}=$ Score of Participants' Perceptions

\section{Result and Discussion}

\subsection{Result}

\subsubsection{English Language Teacher Professional Development (PPG) in Indonesia}

A one-year teacher professional education program was proposed in 2010 by Indonesian government. The main reason behind this program is to improve teacher quality in line with Indonesian Law No. 20/2003 on the National Education System and No.14/2005 on Teachers and Lecturers. This program runs in two semesters including workshop-based courses with 36-40 credit courses running five days per a week, eight hours per day. This program is provided to bachelor degree holders with relevant fields of study who pass the selection. Yet, in 2013 government mandated that PPG has been specialized for graduates who have completed the SM-3T program, a one-year program for selected graduates to teach and contribute in remote areas in Indonesia. The university conducting this program, then namely PPG Post SM-3T, including Indonesia University of Education (UPI), does not have authority to select the participants since it is directly administered by government. The participants are supposed to have had experience in teaching in a certain level of school, promoting innovation in school, supervising extracullicular activities, giving assistance, conducting community empowerment to support the development of education in remote areas and performing social and community tasks [16].

This program is conducted to develop professional teachers, specifically English teachers for secondary level with qualified competences. Based on National Standard of Education in Indonesia, there are four basic competences that must be acquired by teachers including pedagogical competence, professional competence, social competence and personality competence. Pedagogical competence covers 1) knowledge and skills in planning, implementing and assessing instruction (materials on various of text in the 2006 and 2013 English Curricula: interpersonal and transactional conversation and short and long functional texts) in teaching and learning process and 2) following up the result of the assessment through guidance and training for students. Professional competence involves the knowledge and skill of 1) English Language, composed of four skills (listening, speaking, reading and writing) and 2) doing research and continuous professional development. Social competence comprise the ability to develop a harmonious rapport with others such as teachers, students, parents, society, and stakeholders. And Personality competence deals with the ability to become a good role model with a good morality and behaviour and to put forefront the good values.

Similar with other universities, PPG for English Teachers at Universitas Pendidikan Indoneisa is managed and controlled by the English Department. The facilitators are qualified faculty members with at least Master's degree and who specialize on English. The qualification is proved by the certification issued by government. The core contents of the PPG Curriculum involve: 1) subject-specific pedagogy workshop on designing lesson plans, instructional materials and media, assessment procedure and proposals for classroom action research; 2) micro-teaching and or peer teaching;3) subject matter (pedagogical knowledge) and 4) teaching internship and action research. The first three contents are conducted in the first semester and for internship, it is carried out as selected secondary school in the second semester. 
Teaching and learning process in PPG is conducted based on several principles referring to the guidelines of PPG Post SM-3T [17]: learning by doing, active students learning through various learning strategies (learner-cantered), higher order thinking (critical, creative, logical, reflective thinking, problemsolving and decision-making skills), nurturant effects (creating academic atmosphere), ritual feedback mechanism (assessment), ICT integration (utilizing multimedia and ICT in teaching and learning process), and Contextual learning (learning through materials and activities reflecting the real situation that will be found in field).

Thus, this program is basically in line with one of education movements stated in the 5-year WPE with purpose to establish ASEAN Socio-Cultural Community supporting broader access of rural communities to quality education by conducting an ASEAN Community-based program for young volunteer [18]. ASEAN Curriculum Sourcebook states that all member states of ASEAN need to help "ensure that their young citizens in the classroom learn about the interconnectedness among cultures, peoples, economies, governments, and ecosystems, and how these are linked to their own lives" [19]. The ASEAN Curricula sourcebook covers five themes including: knowing ASEAN (its structure, membership, purpose, and approaches, its significance, accomplishment and future challenges); Valuing identity and diversity; connecting global and local, promoting equity and justice; and working together for sustainable future. This should be adopted and adapted by the curriculum of PPG so that the future of professional teachers are well aware of the needs of ASEAN, ASEAN identity and ASEAN integration among their future students. Moreover, as ASEAN integration nears and with the significant contribution English language teacher education can give toward the successful implementation of the program of ASEAN 2015, the management of PPG in each of ten universities in Indonesia have to discuss the program implementation, approaches and content to be incooperated in the program to build participants' awareness of and capacity in collaborating and competing with people from the other ASEAN countries.

\subsubsection{Participants' perceptions towards the PPG implementation in developing their competences (based on National Education Standards of Indonesia).}

Based on the data related to participants' perceptions toward the implementation of English Teacher Professional Development Program in developing their four basic competences, it is achieved: maximum score is 183 ; minimum score is 116 ; Mean is 162.875 , and Standard Deviation is 17.88 .

Table.2 Categorizing Variable of Participants' Perceptions toward Teacher Professional Development regarding to Teachers' Competences

\begin{tabular}{|c|c|c|c|}
\hline Category & Frequency & Percentage & $\begin{array}{l}\text { Cumulative } \\
\text { Percentage }\end{array}$ \\
\hline Extremely Positive $(\mathrm{X}>166)$ & 8 & $50 \%$ & 50 \\
\hline$\overline{\text { Positive }(155<\mathrm{X} \leq 166)}$ & 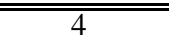 & $25 \%$ & $\overline{775}$ \\
\hline Intermediately Positive $(144<\mathrm{X} \leq 155)$ & 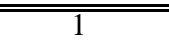 & $6.25 \%$ & $\overline{81.25}$ \\
\hline Negative $(133<X \leq 144)$ & $\overline{22}$ & $12.5 \%$ & 93.75 \\
\hline Extremely Negative $(X \leq 132,7)$ & $\overline{1} 1$ & $6.25 \%$ & 100 \\
\hline
\end{tabular}

Based on the table above, regarding to participants' perceptions toward PPG implementation in developing teachers' professionalism, the frequency of participants' perceptions can be described as follows: $50 \%$ extremely positive, $25 \%$ positive, $6.25 \%$ intermediately positive, $12.5 \%$ negative and $6.25 \%$ extremely negative. Accordingly, it is claimed that the participants' perceptions toward this program in developing their competences can be categorized as extremely positive perceptions. The percentages can clearly be showed by this chart. 


\title{
Categorizing Variable of Participants' Perceptions toward Teacher Professional Development regarding to Teachers' Competences
}
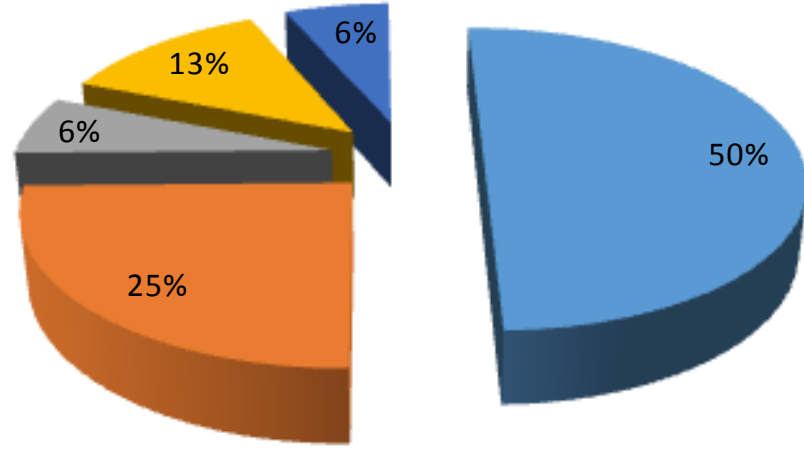

\author{
Extremely Positive $(X>166)$ \\ Positive $(155<X \leq 166)$ \\ - Intermediately Positive $(144<\mathrm{X}$ \\ $\leq 155$ ) \\ Negative $(133<X \leq 144)$
}

Extremely Negative $(X \leq 132,7)$

Chart.1: Categorizing Variable of Participants' Perceptions toward Teacher Professional Development regarding to Teachers' Competences

\subsubsection{Participants' perception towards PPG implementation in meeting the ASEAN Economic Community Programmes demands (based on ASEAN sourcebook)}

Related to participants perceptions toward the implementation of English Teacher Professional Development Program implementation in meeting the ASEAN Economic Community Programmes demands (based on ASEAN sourcebook), it is achieved: maximum score is 76; minimum score is 31; Mean is 162.875, and Standard Deviation is 11.65 .

Table.3 Categorizing Variable of Participants' Perceptions toward Teacher Professional Development regarding to Support ASEAN Economic Community

\begin{tabular}{|c|c|c|c|}
\hline Category & Frequency & Percentage & $\begin{array}{l}\text { Cumulative } \\
\text { Percentage }\end{array}$ \\
\hline Extremely Positive $(\mathrm{X}>65)$ & 2 & $12.5 \%$ & 12.5 \\
\hline 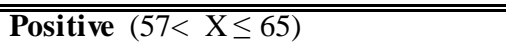 & 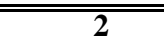 & $12.5 \%$ & $\overline{25}$ \\
\hline Intermediately Positive $(50<\mathrm{X} \leq 57)$ & 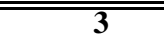 & $\overline{18.75 \%}$ & $\overline{43.75}$ \\
\hline Negative $(46<\mathrm{X} \leq 50)$ & 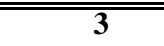 & $\overline{18.75 \%}$ & $\overline{62.5}$ \\
\hline Extremely Negative $(\mathrm{X} \leq 46)$ & $\overline{\overline{6}}$ & $37.5 \%$ & $\overline{100}$ \\
\hline Total & $\overline{16}$ & $100 \%$ & \\
\hline
\end{tabular}

Based on the table above, regarding to participants' perceptions toward PPG implementation in developing teachers' professionalism, the frequency of participants' perceptions can be described as follows: $12.5 \%$ extremely positive, $12.5 \%$ positive, $18.75 \%$ intermediately positive, $18.75 \%$ negative and $37.5 \%$ extremely negative. Thus, it is claimed that the participants' perceptions toward this program in developing their competences to meet ASEAN Economic Community needs can be categorized as extremely negative. The percentages can clearly be showed by this chart. 


\title{
Categorizing Variable of Participants' Perceptions toward Teacher Professional Development regarding to Support ASEAN Economi Community
}

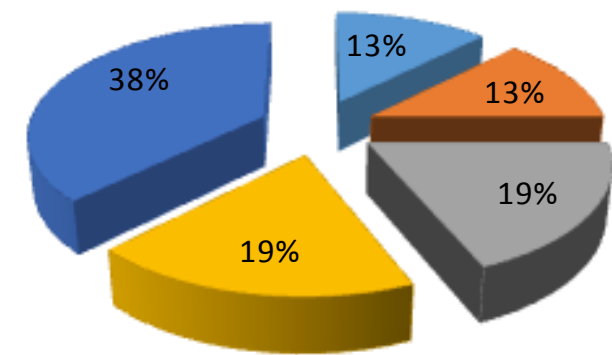

\author{
Extremely Positive $(X>65)$ \\ Positive $(57<X \leq 65)$ \\ Intermediately Positive $(50<\mathrm{X} \leq 57)$ \\ Negative $(46<X \leq 50)$ \\ Extremely Negative $(X \leq 46)$
}

Chart 2: Categorizing Variable of Participants' Perceptions toward Teacher Professional Development regarding to Support ASEAN Economic Community

\subsection{Discussion}

The one-year PPG Post SM-3T for English Teachers is one of concrete movements conducted to improve the quality of English language teachers and to support the successful establishment and development of ASEAN Community in 2015.Based on this study, this program has benefited English teachers in developing their competences (Professional, Pedagogical, Social and Personality Competence) such as in developing their competence based on National Standard of Education in Indonesia. It is shown by the extremely positive perceptions toward this program explored by $50 \%$ of the participants in terms of their competence development. It means that they believe that this program provides activities that are effective in developing their skills and competences: to teach professionally; to build rapport with students; to construct harmonious relationship with society, college, and stakeholders; to develop their carrier in teaching ; and to be role model with good morality and behaviour who puts forefront the good values.

However, since $38 \%$ of participants showed their extremely negative perceptions and $19 \%$ negative perceptions toward the program in developing their competence to support the ASEAN Community 2015, it is essential to reframe the program by referring more to the ASEAN standard of teacher education programs. The content of ASEAN standard involving in ASEAN sourcebook covers five themes that should embody school curricula of in education system of all Member States of ASEAN: valuing identity and diversity, connecting local and global issues, trends and development; promoting equity and justice; and working together for sustainable future. For example, by considering potential to have collaboration, sharing best practices and experts among Member states, and by incorporating ASEAN content into the curriculum of this program. As one of important elements in education, curriculum grabs closer attention of scholars. Richard stated that curriculum should above all focus on knowledge and skills that are relevant to the learners everyday life needs and that the curriculum should be planned to meet the practical needs of society [20]. Accordingly, English teacher professional education needs to be seriously designed and continuously enhanced to produce professional English teachers who meet the qualified standard. In line with Garet, et.al, based on their study claimed that professional development can be done as the mechanism to enhance the quality of teaching [21]. Policies dealing with English Language teachers' education in Indonesia that are formulated to respond to the approaching ASEAN 2015 might not be existed yet. However, as stated before, Indonesian government has moved the paradigm and belief towards a qualified-oriented teacher's paradigm in preparing teachers, including English teachers, like the implementation of PPG. This program is in line with the urgent need for the improvement of the quality of English teachers professional education and the vision and missions of ASEAN 2015. Accordingly, it will contribute to the successful implementation of ASEAN 2015.

\section{Acknowledgement}

In accomplishing this study, through this acknowledgement the writer would like to present my greatest gratitude to LPDP (Indonesia Endowment Fund for Education) that recently funds my study of my master's degree and to numerous people whose support and advise me were psychologically encouraging me during 
writing this study. I would like to express my special gratitude to: my lecturers, my parents and all of my friends (Class C, Master's Students of English Education Program, UPI and LPDP Awardees in Bandung).

\section{References}

[1] ASEAN Secretariat. ASEAN 5-Year Work Plan Education, 2011-2015. Jakarta: ASEAN Secretariat, 2012.

[2] Richards, J.C. Curriculum Development in Language Teaching. Cambridge University Press, USA: Cambridge, 2002, pp. 115

[3] ASEAN Curriculum Sourcebook: A Teaching Resource for Primary and Secondary School to Foster an Outwardlooking Stable, Peaceful, and Prosperous ASEAN Community. Jakarta, Indonesia:ASEAN,2012.

[4] ASEAN Secretariat. Roadmap for an ASEAN Community 2009-2015. ASEAN| ONE VISION ONE IDENTITY ONE COMMUNITY. N.p, n.d. Web. 12 Jan 2017.

[5] Suherdi, D. Towards the 21st Century English Teacher Education: An Indonesian perspective. (2012). Bandung: Celtics Press.

[6] Brown, H.D. Teaching by Principles: An Interactive Approach to Language Pedagogy -2nd ed.. (2001). New York: Addis on Wesley Longman.

[7] Suherdi, D. Buku Pedoman Penyelengggaraan Pendidikan Profesi Guru Bahasa Inggris: Bahan Ajar Pemantapan Kompetensi Akademik. (2013a). Bandung: Celtics Press.

[8] Shaeffer, S. Post-2015 education Scenarios, ASEAN integration, and the post-EFA education agenda in Southeast Asia. A working paper as background document for the SEAMEO Study and Development of Post-2015 Education Scenarios and Post-EFA Agenda in Southeast Asia (December 2013 - May 2014). Southeast.

[9] Freeman,D. Teacher Training, Development, and Decision Making: A Model of Teaching and Related Strategies for teacher education. TESOL Quarterly, 1989. 23(1) pp.27

[10] https://doi.org/10.2307/3587506

[11] Zhu, X., \& Han, X. (2006). Reconstruction of the teacher education system in China. International Education Journal, 7(1), 66-73.

[12] Suherdi, D. Rekonstruksi Pendidikan Bahasan: Sebuah Keniscayaan Bagi Keunggulan Bangsa. (2013b). Bandung: Celtics Press.

[13] Mrowicki,L. Project Work English Competency-Based Curriculum. Portland, Oreg: Nowrtwest Educational Cooperative. 1986.

[14] ASEAN Curriculum Sourcebook: A Teaching Resource for Primary and Secondary School to Foster an Outwardlooking Stable, Peaceful, and Prosperous ASEAN Community. Jakarta, Indonesia: ASEAN, 2012. Pp. 5.

[15] Martya, H. Pengaruh Persepsi Mahasiswat entang Status Sosial Guru dan Program Pendidikan Profesi Guru (PPG). 2015. Yogyakarta: Universitas Negeri Yogyakarta.

[16] Saifuddin Azwar. Penyusunan Skala Psiologi Edisi 2. (2015).Yogyakarta: Pustaka Pelajar.

[17] Kementrian Pendidikan dan Kebudayaan (The Ministry of Education and Culture). Salinan lampiran Permendikbud No.65 Tahun 2013 tentang Standar Proses [Attachment of the regulation of the Misnister of Education and Culture on the standard of Process]. (2013a). Jakarta: Kemendikbud.

[18] Kementrian Pendidikan dan Kebudayaan (The Ministry of Education and Culture). Tentang SM-3T [About SM-3T]. 2014. Available: http://majubersama.dikti.go.id/?page id=203

[19] ASEAN Secretariat. ASEAN 5-Year Work Plan Education, 2011-2015. Jakarta: ASEAN Secretariat, 2012. Pp.7.

[20] ASEAN Curriculum Sourcebook: A Teaching Resource for Primary and Secondary School to Foster an Outwardlooking Stable, Peaceful, and Prosperous ASEAN Community. Jakarta, Indonesia: ASEAN, 2012. Pp.1

[21] Richards, J.C. Curriculum Development in Language Teaching. Cambridge University Press, USA: Cambridge, 2002, pp. 115

[22] Garet, M.S., Portal, A.C., Desimone, L., Birman, B.F., \& Yoon, K.W. What Makes Professional Development Effective? Result from A National Sample of Teachers. American Educational Research Journal Winter 2001 Vol. 38, No.4.

[23] https://doi.org/10.3102/00028312038004915 